Arq. Bras. Med. Vet. Zootec., v.67, n.4, p.1039-1044, 2015

\title{
In vivo biocompatibility of nanostructured Chitosan/Peo membranes
}

\author{
[Biocompatibilidade in vivo de membranas nanoestruturadas de Quitosana/Peo] \\ V.A.S. Vulcani ${ }^{1}$, V.S. Franzo ${ }^{2}$, R.E. Rabelo ${ }^{1}$, A.S. Rabbers ${ }^{3}$, B.M. Assis $^{3}$, \\ M.A. D'Ávila ${ }^{4}$, S.M.B. Antoni ${ }^{5}$ \\ ${ }^{1}$ Universidade Federal de Goiás - UFG - Regional Jataí, Jataí, GO \\ ${ }^{2}$ Universidade Federal do Mato Grosso - UFMT - Cuiabá, MT \\ ${ }^{3}$ Aluno de pós-graduação - Escola de Veterinária e Zootecnia - UFG - Regional Goiânia, GO \\ ${ }^{4}$ Faculdade de Engenharia Mecânica - Universidade de Campinas - UNICAMP - Campinas, SP \\ ${ }^{5}$ Faculdade de Ciências Agrárias e Veterinárias de Jaboticabal - UNESP - Jaboticabal, SP
}

\begin{abstract}
Electrospinning is a technique that allows the preparation of nanofibers from various materials. Chitosan is a natural and abundant easily obtained polymer, which, in addition to those features, proved to be biocompatible. This work used nanostructured chitosan and polyoxyethylene membranes as subcutaneous implants in Wistar rats to evaluate the biocompatibility of the material. Samples of the material and tissues adjacent to the implant were collected 7, 15, 30, 45 and 60 days post-implantation. Macroscopic integration of the material to the tissues was observed in the samples and slides for histopathological examination that were prepared. It was noticed that the material does not stimulate the formation of adherences to the surrounding tissues and that there is initial predominance of neutrophilia and lymphocytosis, with a declining trend according to the increase of time, featuring a non-persistent acute inflammatory process. However, the material showed fast degradation, impairing the macroscopic observation after fifteen days of implantation. It was concluded that the material is biocompatible and that new studies should be conducted, modifying the time of degradation by changes in obtaining methods and verifying the biocompatibility in specific tissues for biomedical applications.
\end{abstract}

Keywords: nanotechnology, biomaterials, electrospinning.

\section{RESUMO}

A eletrofiação é uma técnica que permite a preparação de nanofibras mediante o uso de diversos materiais. A quitosana é um polímero natural, abundante e de fácil obtenção, que, além dessas características, demonstrou ser biocompatível. Este trabalho utilizou membranas nanoestruturadas de quitosana e polióxido de etileno como implantes subcutâneos em ratos Wistar para avaliar a biocompatibilidade do biomaterial. As amostras do material e de tecidos adjacentes ao implante foram retiradas sete, 15, 30, 45 e 60 dias pós-implantação para a observação da integração macroscópica do material aos tecidos e para a preparação de lâminas para exame histopatológico. Verificou-se que o material não estimula a formação de aderências com os tecidos circunvizinhos e que há predominância inicial de neutrofilia e linfocitose, que tendem a decrescer em razão do aumento do tempo, caracterizando um processo inflamatório agudo não persistente. No entanto, o material apresentou degradação rápida, não sendo possível observá-lo macroscopicamente após 15 dias de implantação. Concluiu-se que o material é biocompatível, o que indica que novos estudos devem ser conduzidos, com modificação do tempo de degradação por alterações nos métodos de obtenção e verificação da biocompatibilidade em tecidos específicos para aplicações biomédicas.

Palavras-chave: nanotecnologia, biomateriais, eletrofiação

Recebido em 18 de março de 2015

Aceito em 8 de junho de 2015

E-mail: aloisiosv@hotmail.com 


\section{INTRODUCTION}

Nanotechnology has been standing out over the years due to the versatility in its applications (Agarwal et al., 2009). Such science consists of the development and manipulation of nanometer extension systems, i.e., in scales at the rate of 1 to $100 \mathrm{~nm}$. Therefore, nanotechnology has enabled the obtaining of fibrous membranes with nanoscale diameters, whose high aspect ratio provides great surface area and, consequently, the materials become more available and susceptible to the interaction with other molecules and cells (Faria-Tischer and Tischer, 2012). Several techniques enable the obtaining of nanofibers, being electrospinning one of the methods that feature a wide range of applications. The production mechanism using this technique is due to electrostatic forces that act, most often, in a polymer solution when subjected to an electric field. The process starts when an electric field is applied between the needle of the syringe that sustains the polymer solution and collector base (Ramakrishna et al., 2005).

The existing sources for obtaining nanofibers may be of natural or synthetic origin. When compared to natural fibers, the synthetic ones tend to have superior mechanical properties such as tensile strength and elastic modulus. In addition, it is easier to design the synthetic fibers for specific applications, also eliminating the complicated purification methods of natural raw materials (Dvir et al., 2005). On the other hand, although featuring a greater challenge for the electrospinning technique, the natural raw materials have bioactive multifunctional properties that provide good performance in biological systems with increased biocompatibility (Khor and Lim, 2003). The raw materials also interact better with living organisms, becoming interesting for new applications in the medical field and biological systems.

Chitosan, a natural polymer obtained by alkaline deacetylation of chitin, has aroused great interest in the area of biomaterials due to the favorable characteristics such as the absence of toxicity, antifungal effect, assistance to healing, biodegradability, biocompatibility and bioactivity, in addition to being produced from renewable natural sources (Campana et al., 2007). However, the chitosan electrospinning usually requires the mixture of this material with biocompatible synthetic polymers such as the poly(oxyethylene) (PEO) (Teng et al., 2001). PEO is a hydrophilic nonionic surfactant that, together with chitosan, makes the device even more biocompatible and stable in biological fluids, as it decreases the natural tendency of aggregation (Prego et al., 2006).

Concerning the implantation of biomaterials, whether experimentally or to replace tissues and organs, some aspects should be considered, once there is the application of traumatic surgical procedures, inducing inflammatory responses. Added to that, the material itself can trigger inflammation and immune reactions and, thus, become detrimental to the host organism. In addition, implanted degradable materials should be monitored for a longer period, since the products resulting from degradation may cause different inflammatory responses. In that sense, the level of success in the implantation of the biomaterial is associated to the severity of the inflammatory process triggered, the time needed for the re-establishment of the basic activities of the patient and the time that the implant remains in the body (Oréfice et al., 2006; Kim et al., 2011).

Therefore, this study aimed to analyze the in vivo biocompatibility, by using macroscopic evaluation of the biomaterial and host tissue interaction and histopathological analysis of the tissues adjacent to the nanostructured chitosan/PEO nanofiber membranes applied in the subcutaneous tissue of Wistar rats.

\section{MATERIALS AND METHODS}

The experiment was submitted to the Committee of Ethics and Animal Experimentation of the Federal University of Goiás, registered under number 097/11. All procedures involved in the evaluation of in vivo biocompatibility of the chitosan/PEO nanofiber membrane were conducted at the same institution.

The development of the material was held at the Department of Polymer Technology of the School of Chemical Engineering, State University of Campinas (UNICAMP). The composition of the membranes consisted of $80 \%$ chitosan and $20 \%$ poly(oxyethylene) (PEO). Those membranes were obtained through the electrospinning process using chitosan (Sigma- 
Aldrich) of medium molecular weight with $80 \%$ deacetylation level and $284 \mathrm{cps}$ viscosity at $1 \%$ PA-ACS glacial acetic acid (Synth) and poly(oxyethylene) solution with $900,000 \mathrm{~g} / \mathrm{mol}$ molecular weight (Sigma-Aldrich) (Bizarria et al., 2014). The average diameter of the fibers obtained corresponded to $100 \mathrm{~nm}$. After the obtaining, the materials were sterilized in oxyethylene for surgical use and packed in individual packages.

For the implantation of the samples, 30 young male and female rats (1:1), of the albino Wistar lineage were used, divided into five experimental groups according to the removal of the material (7, 15, 30, 45 and 60 days post-implantation), with six animals per group.

Surgical procedures were performed with the animals under general anesthesia, through intraperitoneal injection of pentobarbital sodium. After shaving the dorsal region, a longitudional incision of approximately $1.5-\mathrm{cm}$ was done on the skin and, then the nanostructured membrane was implanted in the subcutaneous space. Separate simple suture was applied by using a 20 polyamide thread. The antibiotic therapy was based on $10 \%$ enrofloxacin intraperitoneally, in addition to the topic application of $2 \%$ mupirocin-based ointment (Brito et al., 2009). For analgesia, a $0.2 \mathrm{mg} / \mathrm{kg}$ dose of butorphanol was administered subcutaneously during two days (Massone, 2008). After the end of the procedure, the animals were housed in cages and there was clinical follow-up on a daily basis, measuring the temperature and observing the mucous staining the behavior and the consumption of water and ration.

The euthanasia of animals was held on the preestablished days in accordance with each group. For that, a 3\% pentobarbital sodium overdose was used intraperitoneally. At the time of the removal of implanted samples the tissue adherence was classified according to Tab. 1 (Vulcani et al., 2008).

Table 1. Tissue adhesion on the implant in relation to the difficulty of its release from adjacent tissues

\begin{tabular}{cll}
\hline Classification & \multicolumn{1}{c}{ Adherence } & \multicolumn{1}{c}{ Release of the sample } \\
\hline$(+)$ & minimum adherence & $\begin{array}{l}\text { release of the sample of adjacent tissues by gentle } \\
\text { blunt dissection } \\
\text { release of the sample of adjacent tissues by sharp } \\
\text { blunt dissection } \\
\text { impossibility of releasing through blunt dissection }\end{array}$ \\
\hline
\end{tabular}

The fragments removed consisted of implanted membrane and tissue adjacent to the implant. This material was fixed at $10 \%$ buffered formalin with $\mathrm{pH} 7.2$ phosphate solution for 24 hours and, then processed for making permanent blades with Hematoxylin-Eosin and Gömöri Trichrome stain, according to Tolosa et al., 2003.

At the optical microscope, the occurrence and incidence of variables related to the inflammatory process and metaplasias was verified (Table 2).

The microscopic analysis incorporated objective data obtained through histometry. For that, a binocular microscope (Olympus ${ }^{\circledR}$ BX60sr) with photomicrotomography equipment, a camera for image capture and an image analyzer (ImagePro-Plus, Cybernetics, California, USA) were used. From every histological cut, 20 random fields were chosen for cell count.

Table 2. Findings of histological examination of the samples

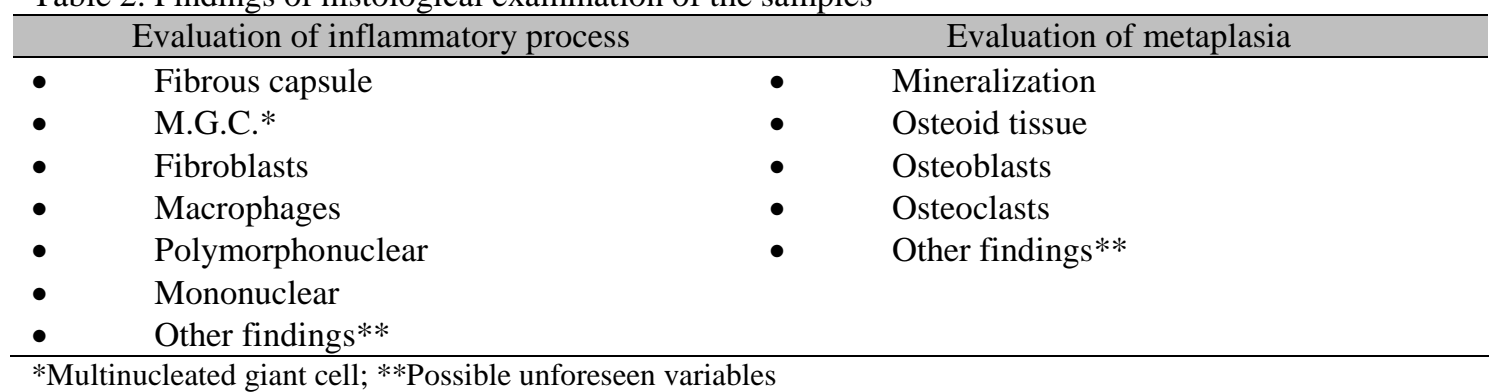


For the cell count data, the normality analysis of the studentized errors (Cramer-Von Mises test) and of variance homogeneity (Brown-Forsythe test) was performed. After verifying the compliance with those assumptions, the data were subjected to analysis of variance by using the General Linear Model of the SAS® program and, in case of difference $(\mathrm{P} \leq 0.05)$, the means were compared by the Tukey test, considering the $5 \%$ probability level.

\section{RESULTS AND DISCUSSION}

When the implants were removed, there was minimal adherence in the G1 and G2 groups (7 and 15 days, respectively), except for one sample in both groups, whose adherence was moderate. As for the G3 group (30 days), the adherence was minimal in all samples. In addition, there was considerable decrease in the amount of material and even complete degradation.

Brito et al. (2009), in a similar study, also had trouble finding the site of the procedure due to the degradation of the material, after the same period of implantation. That is due to the fact that chitosan is fragmented by enzymatic action, as well as the lysozyme, when contacting the animal tissues (Laranjeira and Fávere, 2009).

Azab et al. (2007), on their turn, stated that oxidizing agents released by neutrophils in the inflammatory site are responsible for the degradation of crosslinked chitosan after implantation. The same researchers believe that macrophages then phagocyte the debris, eliminating the material from the organism. In addition, the degradation period seems to depend on the level of acetylation of the chitosan used, a factor that also interferes with the level of mechanical resistance to the material (Spin Neto et al., 2008).

Kim et al. (2011) demonstrated that, when applying chitosan with a high level of deacetylation in the spinal cord of rats, both intrathecally and intramedullary, it showed no sign of degradation, even after six months of implantation. That is due to the fact that the lysozyme requires at least three consecutive acetylated monomers to perform the cleavage of the molecule (Varum et al., 1996). Also associated to the low inflammatory response, this material proved to be a favorable option for the use in tissue restructuring (Kim et al., 2011).

For the histomorphometric analysis, which aimed to verify the cellular processes of inflammation, a 0 to 5 rating (zero for the no-occurrence and five for high occurrences) was assigned to every variable. Thus, after seven days, as expected, the predominance of polymorphonucleated cells, $2^{+} / 5$ on average, was observed, as well as a moderate amount of lymphocytes, $1^{+} / 5$ on average. Both cell types were in greater concentration at the interface of the material and the adjacent tissue, and not inside the implant (Figure 1).

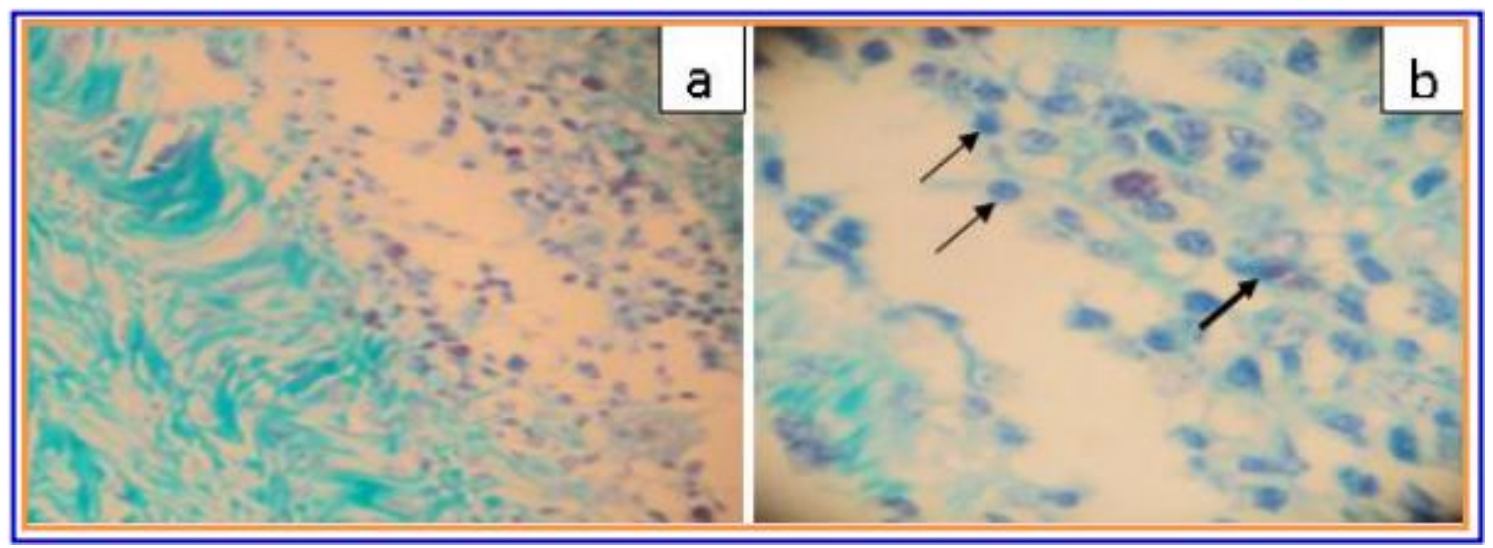

Figure 1. Photomicrographies of chitosan/PEO sample removed from Wistar rats sample seven days postimplantation. In A, there are blue stained collagen fibers and leukocyte invasion. In B, there is the largest increase, highlighting the leucocytes, with predominance of neutrophils (thin arrows) and leukocytes (thick arrow). There are also increases of 200 and 400 times respectively and Gömöri Trichrome stain. 
In later moments, the amount of neutrophils decreased $\left(1^{+} / 5\right.$ on average), while the amount of lymphocytes increased $\left(2^{+} / 5\right.$ on average). The lymphocytosis had significant increase 15 days post-implantation, however, they decreased over time due to the intense degradation of the material. After 30, 45 and 60 days postimplantation, the material had been completely degraded, evidencing the interface of the biomaterial and the adjacent tissue formed by a small capsule of conjunctive tissue (Figure 2).

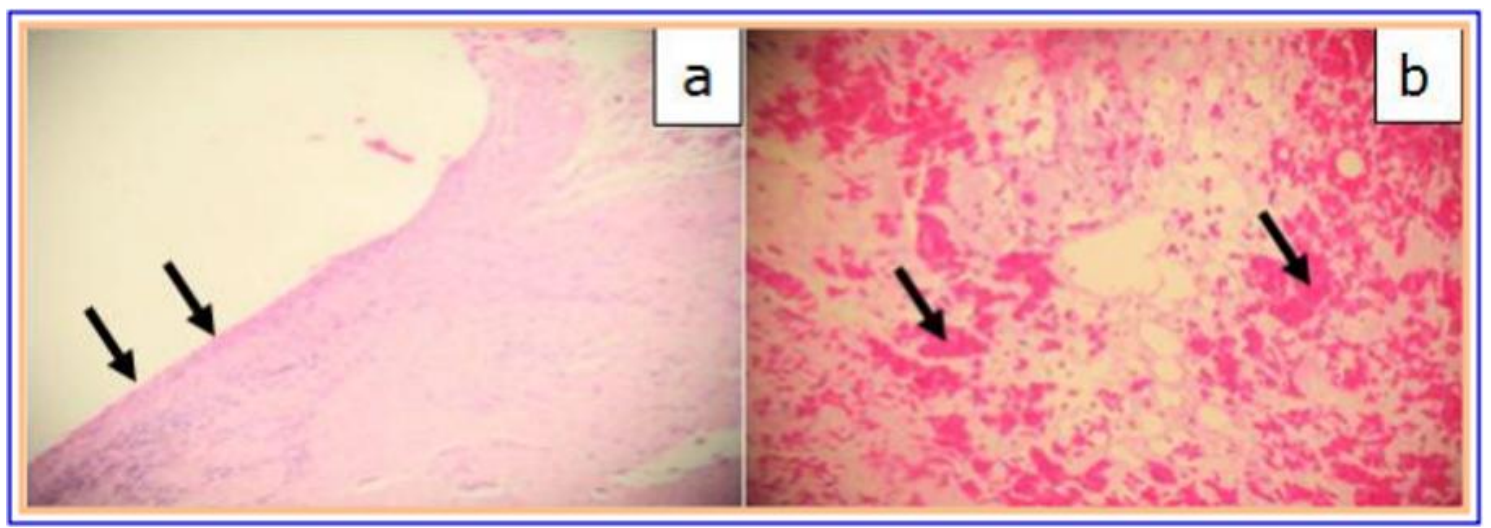

Figure 2. Photomicrographies of chitosan/PEO sample removed from Wistar rats sample removed 15 days post-implantation. In $\mathrm{A}$, there is the interface of fibrosis and the tissue adjacent to the implanted material. The material was degraded, remaining only the fibrous tissue (arrows). Increase of 200 times and Hematoxylin-Eosin staining. In B, there are fragments of intense degraded material (arrows). Increase of 400 times and Hematoxylin-Eosin staining.

Research suggests that chitosan biomaterials accelerate the infiltration of lymphocytes in the early stages of the inflammatory process, due to the considerable increase of osteopontin, a phosphoprotein that increases the cellular connections in the healing wound. The molecular structure of chitosan itself, similarly to the hyaluronic acid, strengthens the indication to the use of that biopolymer, promoting healing and tissue repair (Spin Neto et al., 2008). However, in another study, where the chitosan membrane was associated to stem cells, there was less inflammatory response when compared to the control group. This fact may be explained by the likely immunosuppression caused by the transplanted stem cells (Kang et al., 2010).

Concerning the macrophages, seven days later a moderate concentration $\left(0^{+} / 5\right.$ on average) was observed, which tended to increase 15 days later $\left(1^{+} / 5\right.$ on average), but with no significant difference. After 30 days there was significant decrease of the amount of macrophages, however, the material had already suffered total degradation.

The ibroblast count showed that after seven days there was slight presence around the implant
$(0+/ 5$ on average), increasing significantly after 15 days $\left(2^{+} / 5\right.$ on average) and showing its largest amount 30 days post-implantation $\left(3^{+} / 5 \mathrm{on}\right.$ average). After 45 and 60 days the healing process was consolidated, with no difference in the amount of fibroblasts.

Intense neovascularization was also noticed around all implants in quantities varying very little according to the time of their removal. Other researchers, after the implantation of the material containing chitosan in its constitution, also observed the formation of blood vessels in the area of the procedure (Azab et al., 2007; Brito et al., 2009; Kang et al., 2010).

Regarding the material degradation, in the first days post-implantation there was evident decreasing of the mass, both inside and on the surrounding of the sample, which was accentuated until the total degradation of the material. In general, biomaterials consisting of chitosan cause minimal reaction of foreign bodies (Brito et al., 2009; Laranjeira and Fávere, 2009). The formation of tissue with normal granulation associated to angiogenesis is related to the healing response and that effect has been suggested due to the bioactivity of the material, a 
factor that stimulates the interaction of the material with the host (Laranjeira and Fávere, 2009).

The verification of metaplasia in the region of the implant did not show meaningful results on cellular change, and there were no differences among the groups in all periods studied concerning the gender of the animals.

\section{CONCLUSIONS}

The inflammatory process resulting from the implantation of nanofiber chitosan/PEO membranes was acute and descending according to time, and provided minimal adherence on the interface of the biomaterial and adjacent tissues. The material suffered severe degradation, not being possible to observe it macroscopically in periods after 15 days. It was concluded that the material is biocompatible, suggesting its suitability for future studies and applications.

\section{REFERENCES}

AGARWAL, S.; WENDORFF, J.H.; GREINER A Use of electrospinning technique for biomedical applications. Polymer, v.49, p.5603-5621, 2009.

AZAB, A.K.; DOVINER, V.; ORKIN B. et al. Biocompatibility evaluation of crosslinked chitosan hydrogels after subcutaneous and intraperitoneal implantation in the rat. J. Biomed. Mater. Res., v.83, n.2, p.414-422, 2007.

BIZARRIA, M.T.M.; D’ÁVILA, M.A.; MEI, L.H.I. non-woven nanofiber chitosan/peo membranes obtained by electrospinning. Braz. J. of Chemic. Eng. v.31, n.1, p.57-68, 2014.

BRITO, M.K.M.; SCHELLINI, S.A.; PADOVANI, C.R. et al. Inclusões de quitosana no subcutâneo de rato: avaliação clínica, histológica e morfométrica. $A n$. Bras. Dermatol., v.84, p.35-40, 2009.

CAMPANA, F. S.; CURTI, E.; ABREU F. et al. Extração, estrutura e propriedades de $\alpha$ - e $\beta$ - quitina. Quim. Nova., v.30, p.644-650, 2007.

DVIR, T.; TSUR-GANG, O.; COHEN, S. Designer scaffolds for tissue engineering and regeneration. Isr. J. Chem., v.45, p.487-494, 2005.

FARIA-TISCHER, P.C.S.; TISCHER C.A Nanobiotechnology, biomaterials and biological application of nanostructures. Bioch. Biotech. Rep., v.1, p.32-53, 2012
KANG, Y.M.; LEE, B.N.; KO, J.H. et al. In vivo biocompatibility study of electrospun chitosan microfiber for tissue engineering. Int. J. Mol. Sci., v.11, p.4140-4148, 2010.

KHOR, E.; LIM, L.Y. Implantable applications of chitin and chitosan. Biomaterials, v.24, p.2339-2349, 2003.

KIM, H.; TATOR, C.H.; SHOICHET M.S. Chitosan implants in the rat spinal cord: biocompatibility and biodegradation. J. Biomed. Mater. Res. A, v.97, p.395404, 2011

LARANJEIRA, M.C.M.; FÁVARE V.T. Quitosana: biopolímero funcional com potencial industrial biomédico. Quim. Nova, v.32, p.672-678, 2009.

MASSONE, F. Anestesiologia veterinária: farmacologia e técnicas. 5.ed. Rio de Janeiro: Guanabara Koogan, 2008. 592p.

ORÉFICE, R.L.; PEREIRA, M.M.; MANSUR, H.S. Biomateriais: fundamentos e aplicações. Rio de Janeiro: Cultura Médica, 2006.

PREGO, C.; FABRE, M.; TORRES, D. et al. Efficacy and mechanism of action of chitosan nanocapsules for oral peptide delivery. Pharm. Res. v.23, p.549-556, 2006.

RAMAKRISHNA, S.; FUJIHARA, K.; TEO W.E. $e t$ al. An introduction to electrospinning and nanofibers. Singapore: World Scientific, 396 p., 2005.

SPIN-NETO, R.; PAVONE, C.; FREITAS R. M. et al. Biomateriais à base de quitosana com aplicação médica e odontológica: revisão de literatura. Rev. Odontol. UNESP., v.37, p.155-161, 2008.

TENG, I. W.; KHOR, E.; TAN, T. K. et al. Current production of chitosan from shrimp shells and fungi. Carbohydr. Res., v.332, p.305-316, 2001

TOLOSA, E. M. C.; RODRIGUES, C. J.; BEHMER, O. A. Manual de técnicas para histologia normal e patológica. 2.ed. São Paulo: Manole, 2005. 341p.

VARUM, K.M.; HOLME, H.K.; IZUME M. et al. Determination of enzymatic hydrolysis specificity of partially $\mathrm{N}$-acetylated chitosans. Biochim Biophys Acta, v.1291, p.5-15, 1996.

VULCANI, V.A.S.; MACORIS, D.G.; PLEPIS, A.M.G. et al. Obtenção, caracterização e aplicação cirúrgica de matrizes de colágeno na parede abdominal de equinos. Ciênc. Anim., v.9, p.778-785, 2008. 